\section{Musick Memorial Trophy}

THe first award of the Musick Memorial Trophy of the Royal Aeronautical Society has been made to Mr. Arthur Gouge, chief designer of Messrs. Short Brothers, Ltd. The Trophy was founded in 1938 as a memorial to Captain Edwin Musick and his six companions who were lost on January 12, 1938, on the Samoan Clipper, in the South Pacific, during the first commercial flight from U.S.A. to Auckland, New Zealand. It is awarded annually to "the group, body or individual who have made the contribution, development or improvement which by its practical application has become most effective in furthering the safety of aircraft with special regard to trans-oceanic aviation". The award is confined to citizens of the British Commonwealth of Nations and the United States of America. The Trophy, in silver, is valued at $\mathfrak{£ 2 5 0}$.

\section{The Night Sky in March}

THe date of the spring equinox is March $21^{\mathrm{d}} 12^{\mathrm{h}}$ U.T. The moon is full on March 5 at $18^{\mathrm{h}}$ and new on March 21 at $2^{\text {h }}$. $\lambda$ Geminorum (magnitude $3 \cdot 6$ ) is occulted on March 2, the disappearance taking place as seen from Greenwich at $0^{\mathrm{h}} 23 \cdot 6^{\mathrm{m}}$ at position angle $154^{\circ}$ from the north point of the moon's disk. $x$ Cancri, a fifth magnitude star, is occulted on March 3 at $18^{\mathrm{h}} 23 \cdot 4^{\mathrm{m}} ; 97$ Tauri (mag. $5 \cdot 1$ ) is also occulted on March 26 at $18^{\mathrm{h}} 43 \cdot 6^{\mathrm{m}}$. Lunar conjunctions with the planets occur as follows : on March 13 with Mars; on March 17 with Venus; on March 22 with Mercury at $11^{\mathrm{h}}$ and with Saturn at $17^{\mathrm{h}}$. Jupiter is in conjunction with the sun on March 6. Neptune is in opposition on March 13. Mercury is at greatest elongation ( $18^{\circ}$ E.) on March 17 . Some ten days previously it may be possible to detect this elusive planet in the evening twilight at $18 \frac{1}{2}^{\mathrm{h}}$ nearly due west and at $5^{\circ}$ above the horizon. Saturn is an evening star setting at about $20^{\mathrm{h}}$ in mid-March. Venus, a bright morming star (mag. $-3 \cdot 8$ to $-3 \cdot 6$ ), rises before $5^{\mathrm{h}}$, preceded by Mars, the rising of which is more than two hours earlier. Under suitable conditions, the Zodiacal Light may be seen after sunset during this month. In the middle of March, Sirius is due south about an hour after sunset. As the sky darkens, the rich assembly of bright stars west of the meridian contrasts with the sparseness of the eastern half of the sky. It is in this less spectacular region, however, that the great spacepenetrating telescopes are able to record the remote extra-galactic nobulæ, of which notable clusters are in the constellations of Leo and Ursa Major.

\section{Announcements}

Prof. Henry Norris Russell, director of the Princeton University Observatory, has been elected correspondant of the Section of Astronomy of the Paris Academy of Sciences in succession to the late Prof. E. W. Brown.

MR. W. S. DAvey has been appointed head of the Chemical Division of the Rubber Research Institute to succeed Dr. E. Rhodes, who has resigned to take up a post under the British Rubber Producers'
Research Association. Mr. Davey is at present senior chemist on the staff of the London Advisory Committee for Rubber Research (Ceylon and Malaya) at the Imperial Institute.

Prof. Helmuth Scheel has been appointed president and Prof. Theodor Vahlen vice-president of the Prussian Academy of Science.

The third International Congress, under the auspices of the International Union Against Cancer, will be held in Atlantic City, New Jersey, U.S.A., on September 11-16 under the presidency of Prof. F. Carter Wood, director of the Institute of Cancer Research in Columbia University. Further information can be obtained from the Secretary-Treasurer, Dr. Donald S. Childs, 713 E. Genesee Street, Syracuse, New York.

A CONFERENCE on "China in World Affairs and Our Responsibility" is to be held in the Friends House, Euston Road, London, on March 10-11, under the auspices of the China Campaign Committee. The Conference will discuss the present position in China, economic, political and educational reconstruction in China, the rebuilding of universities, etc. Further information can be obtained from the National Organizer, China Campaign Committee, Parliament Mansions, Orchard Street, London, S.W.I.

THE Meteorological Association of the International Union of Geodesy and Geophysies will be held in Washington during September 4-15, under the presidency of Prof. S. Chapman. The subject of Prof. Chapman's address will be "Atmospheric Tides and Associated Phenomena", and the address will be followed by discussion. Other subjects for discussion will include recent developments in aerology and electric and magnetic phenomena of the atmosphere. Further information can be obtained from the General Secretary of the Assembly, Dr. J. A. Fleming, 5241 Broad Branch Road, N.W., Washing. ton, D.C.

THE Zoological Society of London announces that, beginning with this year, its publications will be reorganized. One or more parts of the Transactions will appear each year and the Proceedings will appear in two series, as follows: $(A)$ general and experimental; $(B)$ systematic and morphological. These can be subscribed for either singly or in any combination. Proceedings $(C)$ will no longer be published. In future an "Abstract and Agenda of the Scientific Meetings" will be published, and may be obtained for an annual subscription of six shillings. One volume of $(A)$ and one of $(B)$ will be published annually. Further information can be obtained from the Secretary, Zoological Society of London, Regent's Park, London, N.W.8.

We regret that the price of Prof. J. D. Bernal's book "The Social Function of Science", noticed in NATURE of February 18, p. 262, was stated incorrectly to be $2 s$. $6 d$. net. The price of the volume is 12s. $6 d$. net. 